\title{
Youth Place Attachment and Quality of Life Index in Public Housing
}

\author{
Kamarul Ariff Omar ${ }^{1 *}$, Dasimah Omar ${ }^{1}$, \\ Saberi Othman ${ }^{2}$, Zaharah Mohd Yusoff ${ }^{1}$
}

${ }^{1}$ Faculty of Architecture, Planning and Surveying, Universiti Teknologi Mara (UiTM), 40450

Shah Alam, Selangor, Malaysia

${ }^{2}$ Faculty of Science and Mathematics, Universiti Pendidikan Sultan Idris (UPSI), 35900

Tanjong Malim, Perak Malaysia

Kamarulariffomar@gmail.com

\begin{abstract}
This study examines the quality of life (QoL) satisfaction through place attachment theory upon neighbourhood area among youth in Kuala Lumpur. The objectives are to test the impact of neighbourhood sense of place on QoL index. For place attachment, the environmental factors closest to the home of the residents exerted a greater influence than the more distal factor. These findings contribute to understanding the relationship between place attachment theory and quality of life among youth. The discussion also considers personal dimensions of place belonging and identifying associations amongst them as ways to explore youth quality of life in the PPH.
\end{abstract}

Keywords: Quality of Life; Place Attachment Theory; Youth; Public Housing

eISSN 2398-4279 @ 2018. The Authors. Published for AMER ABRA cE-Bs by e-International Publishing House, Ltd., UK. This is an open access article under the CC BY-NC-ND license (http://creativecommons.org/licenses/bync-nd/4.0/). Peer-review under responsibility of AMER (Association of Malaysian Environment-Behaviour Researchers), ABRA (Association of Behavioural Researchers on Asians) and $c E-B s$ (Centre for EnvironmentBehaviour Studies), Faculty of Architecture, Planning \& Surveying, Universiti Teknologi MARA, Malaysia.

DOI: https://doi.org/10.21834/ajqol.v3i12.155 


\subsection{Introduction}

Neighbourhood determines equally as a 'place' for the inquiry to be carried out in some circumstances themes. It embraces the significance of the physical change, physical boundaries and local landmarks in creating a sense of belonging and identify on representing the quality of life among the dwellers (Omar et al., 2016b). Place indicated as a unit of 'ecofriendly experience' in conjunction of identifications, affects, and behaviours of the people who are experiencing the neighbourhood environmental spaces. The concept of neighbourhood environment usually measured by assessing neighbourhood networks, instrumental and emotional social support available within the area, casual interaction with neighbours and other resources potentially available to all members of the community structure (Omar et al., 2016a).

Place can be understood as a unit on accomplishment for 'environmental experience' (Canter, 1986), a conjunction of intuitions, affect and behaviours of the people who are experiencing the area (Canter, 1991). The word 'place' delivers many different dimensions such as physical size, tangible vs. symbolic, known and experienced versus unknown or not experienced (Pretty, et al., 2003). Lochner et al. (1999) concluded that neighbourhood solidity is a community level characteristic, with several instruments having been designed to quantify this collective attribute (Young, et al., 2004).

Place attachment refers to the emotional and responsive sense of relationships that characters form with unambiguous places (Kyle et al., 2005). These links grant physical places with emotional sense and personal experience (Johnstone, 2012) and manifest as a constant tendency to continue close bonds to accurate, inclusive, and singular places (Kleine \& Menzel-Baker, 2004). These pledges form after 'natural interaction' and become resilient as further time is consumed in the same location (Lewicka, 2011).

According to Bennett (2014), 'belonging' is a hazy term that is yet but central to the character and everyday life of people. History, people, and place are the three bases of belonging (Bennett, 2014; Miller, 2003). Belonging can be verbalised regarding "multiple social relationships broadening between past, present, and future generations and places" (Bennett, 2014, p. 658). A sense of belonging, conversely, is not only built on social relationships with others (Mellor et al., 2008) but is formed in the course of physical and mental dealings with places that are both attitudinal and thought (Peter et al., 2016).

Youth engagement has been called the "missing link" in organized activity research (Bartko, 2005; Kamarul Ariff Omar et al., 2016a). Rational engagement in precise space may be crucial for constant participation and interest of developmental reimbursements. Flow theory (Larson, 2000) delivers a useful perspective from which to hypothesise thought engagement in neighbourhood space in public housing. A course experience, defined as an emotional defined of involving total involvement in an activity, is assumed to transpire once challenges individual skills emerged (Rathunde \& Csikszentmihalyi, 2006; Akiva et al., 2013).

This study achieved the understood of the combination of both sociology and physical discipline in identified the quality of life index among young people living the marginalised community in the public housing. The measurement comprises the surrounding physical development on both inside and outside the neighbourhood catchment. The aims are to examine the youth QoL index in conjunction with physical development consist of variety 
public facilities towards 'place attachment' method of validity. Therefore, the objective of this study is to test the impact of neighbourhood sense of place on QoL index.

\subsection{Methodology}

\subsection{Respondents and Demographics' Determination}

The study was initiated by conducting two focus group discussions (FGD). The first group targeting the youth consist of 12 (twelve) participants, and the second group consists of 12 (twelve) related stakeholders, parents, and residential committee members. The participants of the first group that is representing the youth were selected randomly according to several criteria. They were representing both female and male gender, age between 15 to 25 years old, and by different the races (Malay, Chinese, Indian). They were chosen among students, employed and unemployed and including house-wife.

The second group representing the stakeholders consists of six (6) participants of the PPR Residents' Committee members (two participants), a Town Planner from Kuala Lumpur City Hall (DBKL), a Town Planner from Federal Department of Town and Country Planning Department, Headquarters, Kuala Lumpur and two members of the Malaysian Youth Council Committee.

The next stage is the quantitative data collection. A set of the questionnaire has been developed through the variable and highlighted subjects from the FGD sessions. The survey contains Part A; respondents' background and Part B; respondents' satisfaction level with the outdoor features and space provision in the study area (Kerinchi's People Project Housing). A total of 400 questionnaires were distributed to the youth age 15-25 randomly. These respondents were selected using 'snowball' sampling technique because the total number of youth live there was not available. This survey took about 2 (two) weeks because most of the respondents were available during their leisure time at about five (5) p.m. after school and after working hours.

\subsection{Quality of Life (QoL) Analysis}

This study explored youth well-being index in the public housing neighbourhood area. There is eight (8) domain of the index value: standard of living, health, physical activity, emotion, safety, participation in the community, future hope, and moral values (Othman et al., 2016). The unit of analysis is the index percentage in correlation with respondents' satisfaction level for public spaces and facilities. By using a 1-5 scale of satisfactory, the results of each domain converted into percentage from overall mean and standard deviation. The numbers also were divided by gender in conjunction to raise the comparative result between both male and female quality of life.

\subsection{Place Attachment Inventory (PAI) Analysis}

The PAl is intended to measure place attachment, which is an affective (emotional) response to places that may influence place dependence and sense of belonging, and which may vary with factors such as sufficiency, accessibility, safety, etc. The items of inventory represent 
the surrounding public spaces and facilities used by the neighbourhood. The results than are shown in mean value to specified the level of respondents' feedback on each facility/spaces according to the factor of PAl analysis.

\subsection{Results and Discussion}

\subsection{Focus Group Discussion Report}

The 'space' refers to an area for the neighbourhood users such as adolescence to have leisureliness and outdoor activities. These areas include soccer field; playground, multipurpose courts, and other green section appear proximate the neighbourhood area. According to numerous quoted proclamations, the insufficient space has affected the youth quality of life and satisfactory on a sense of place. This situation even causes them to stay at home doing nothing or heading to shopping mall rather having genuine social interaction. This is an act of early stages in organizing their activities by allowing for surrounding limitations (Schuster et al., 2013).

"Some spaces are restricted to childhood play because most of the residents put their flower pots within the access pathway such as the pedestrians, green area and even at the stairs." (Adolescence respondent number 2)

"..., the facilities are not meant for youth only. This area is a community belonging where children can use it; an adult can use, and even for outsiders to use. So this area is not special for youth facilities as futsal pitch should be used by everyone."

(Residents' Committee member 1)

Based on the 'stakeholders' focus group discussion, one respondent indicated out the issue regarding unsuccessful youth engagement in the community interaction. The problem is the result of the dismissal into residents' neighbourhood committee as they refuse to elect youth representatives in the committee board as well as decision-making process (. This situation always occurred in the community meetings in which stemmed in the marginalization among youth. The residents' committee declined to snoop the grumbles and difficulties challenged by these vulnerable ages. Based on the overall conversation recorded, some issues have been highlighted to cultivate some keyword that continuously mentioned by respondents from both FGD sessions.

- Accessibility and range

- Sufficiency

- Comfortable

- Maintenance

\subsection{Quality of life index analysis}

Results of the study focus on the quality of life index among adolescents in this marginalized 
community according to both gender descriptive statistics. Table 3 shows the quality of life index for the entire samples within both genders of youth at Lembah Pantai. The majority of the samples were for the regular assessment. The mean $(M)$ value is suggesting that youth in this marginalized community perceived moderate QoL classification. They appeased with their overall standard of living by $73.50 \%$ same as the physical activities. The lowest score of QoL index rating is participation in the community, symptomatic of not thriving adapted to the community interface or decide on staying away from the activity, even more, the whole neighbourhood surrounding environment.

The QoL index between male and female youth do not fluctuate much, but percentage for male marginally higher compared to female. Analysis of gender showed that male suggestively has a positive perception of a standard of living $(P=0.0088,<0.05)$, and perception of health $(P=0.0240,<0.05)$. The rest of the $Q 0 L$ index does not show the substantial variance between male and female. Moreover, male respondents perceived more healthy compared to female, this supported by the other domains from having more physical activities $75.22 \%$ (male) to female $(71.29 \%$ ) and highly participate in the community, male (71.33) while female (65.71\%).

Table 3. Quality of life index by gender of youth at Lembah Pantai, Kuala Lumpur

\begin{tabular}{|c|c|c|c|c|c|c|}
\hline \multirow[t]{2}{*}{ Quality of Life domains } & \multicolumn{2}{|c|}{ All Samples $(n=400)$} & \multicolumn{2}{|c|}{ Male $(n=224)$} & \multicolumn{2}{|c|}{ Female $(n=176)$} \\
\hline & M1 & SD & M2 & SD & M3 & SD \\
\hline Standard of living & 73.50 & 21.20 & 75.00 & 21.00 & 72.14 & 21.42 \\
\hline Health & 73.81 & 22.11 & 76.89 & 19.60 & 69.86 & 24.46 \\
\hline Physical activity & 73.50 & 22.20 & 75.22 & 21.26 & 71.29 & 23.22 \\
\hline Emotion & 71.75 & 23.12 & 72.56 & 22.90 & 70.71 & 23.43 \\
\hline Safety & 70.69 & 24.70 & 71.44 & 25.41 & 69.71 & 23.80 \\
\hline Youth participation in community & 68.88 & 23.15 & 71.33 & 21.53 & 65.71 & 24.80 \\
\hline Future hope & 74.38 & 23.21 & 74.78 & 23.02 & 73.86 & 23.50 \\
\hline Moral values & 75.69 & 23.17 & 77.78 & 21.54 & 73.00 & 25.00 \\
\hline Mean & 72.93 & 17.03 & 74.57 & 15.39 & 70.80 & 18.80 \\
\hline
\end{tabular}

\subsection{Respondents' awareness of place identity and dependency}

This section examines the number of respondents' feedback upon the identity and dependency throughout the spaces and facilities provided around the public housing neighbourhood, indicating availability and usage for place identity and dependency. Table 4 shows the result of both components. Health and educational facilities showed the highest positive awareness by respondents on its availability. However, these young people are not actively using the facilities compared to commercial space/facilities. Respondents stated the lowest feedback under the educational dependency as they are interested in having physical activities and hanging out nearby the commercial spaces in leisure time.

Nevertheless, the youth in this public housing are not in the attachment to the library. They were aware of its availability, and this resulted in an issue in the sense of interest for the library in public housing neighbourhood. The similar situation also happens to some of the recreational spaces element in which there was a lack of usage by the young people. 
Their attachment to these facilities are minimal and lack in the sense of belonging to the other users in general. By looking into the usage column, the youth were depending more on grocery shop ( $n=383$ ) stated the answer "yes." The neighbourhood has only one (1) unit of a grocery shop to serve six (6) housing blocks. Concurrence to this matter, grocery shop is one of the highest dependency items in this public housing by the adolescents.

The second highest usage element mentioned is the restaurant or café with $n=370$ out of 400 respondents use the facilities. Youth nowadays prefer this kind of spaces to spend their leisure rather than having outdoor activities in the recreational facilities or spaces. This result has proof the issue arise from the FGD report, highlighting on the insufficient of outdoor features in the urban PPH neighbourhood. For community hall, $33.9 \% \quad(n=135)$ of respondents stated not using the facilities, and this correlates the lower index for participation in the community activities. The library also indicated a higher value of not being used as stated by $n=158(39.5 \%)$. This facility should be used for community interaction environment. However, soccer field recorded with a higher value among of the not dependent item $(n=195)$. Soccer field should play an important role in creating good interaction environment space for the dwellers. The youth sense of belonging in this urban public housing does not intentionally increase by this space.

Table 4. Public Spaces and Facilities availability and usage by respondents

\begin{tabular}{|c|c|c|c|c|c|}
\hline \multicolumn{2}{|c|}{ Types of Public Space and Facilities } & \multicolumn{2}{|c|}{$\begin{array}{l}\text { Availability } \\
\text { (identity) } \\
(n=400)\end{array}$} & \multicolumn{2}{|c|}{$\begin{array}{l}\text { Usage } \\
\text { (dependency) } \\
(n=400)\end{array}$} \\
\hline & & Yes & No & Yes & No \\
\hline \multirow[t]{3}{*}{ 1. $\quad$ Educational } & Library & 381 & 19 & 242 & 158 \\
\hline & Primary school & 390 & 10 & 331 & 69 \\
\hline & Secondary school & 390 & 10 & 343 & 57 \\
\hline 2. $\begin{array}{l}\text { Community } \\
\text { interface }\end{array}$ & Community hall & 391 & 9 & 265 & 135 \\
\hline \multirow{5}{*}{ 3. $\quad$ Religious } & Mosque & 380 & 20 & 363 & 37 \\
\hline & Surau & 380 & 20 & 358 & 42 \\
\hline & Buddhist Temple & 4 & 396 & 4 & 396 \\
\hline & Hindu Temple & 143 & 257 & 21 & 379 \\
\hline & Church & 195 & 205 & 395 & 5 \\
\hline \multirow[t]{6}{*}{ 4. Recreational } & Futsal court & 399 & 1 & 254 & 146 \\
\hline & Badminton court & 381 & 18 & 215 & 185 \\
\hline & Soccer field & 377 & 23 & 205 & 195 \\
\hline & Recreational park / playground & 376 & 24 & 251 & 149 \\
\hline & Gymnasium & 5 & 395 & 0 & 400 \\
\hline & Jogging track & 331 & 69 & 213 & 186 \\
\hline \multirow[t]{2}{*}{ 5. Health } & Gov. clinic & 398 & 2 & 345 & 55 \\
\hline & Private clinic & 380 & 20 & 313 & 87 \\
\hline \multirow[t]{3}{*}{ 6. Commercial } & Grocery & 395 & 5 & 383 & 17 \\
\hline & Mini mart & 371 & 29 & 344 & 56 \\
\hline & Restaurant /café & 393 & 7 & 370 & 30 \\
\hline
\end{tabular}

\subsection{Place Attachment Inventory (PAI) analysis by Respondents}

The average mean value of each PAI variables answered by respondents highly points out the ranking on placement index. Based on Table 3, it shows the average mean of 
respondents' satisfaction with public spaces and facilities. The mean has been clarified to measure the satisfaction level; sufficiency, comfortable, safety, ease, accessibility, and maintenance. The highest percentage showed the most influence to user place attachment. Table 5 indicated the highest PAI index of commercial (79.4\%), educational facilities by $77.2 \%$, followed by community interaction $(76.4 \%)$, health $(75.8 \%), 63.8 \%$ on religious and the lowest is recreational by $60.8 \%$. The ranking is not similar to Table 4 results. For example, recreational space shows a positive sense of belonging and dependency in Table 4, but still not satisfied to the users in some factor like; sufficiency and comfortability by an average of 3.0 - 3.6 of mean value as shown in PAI index column in Table 5.

The commercial spaces achieved the highest rank especially on restaurant/cafe because most of the young people often hanging out there among the peer group. The facilities showed the high mean value for each variable; v1 $=4.08$, v2 $=3.95$, v3=4.06, v4=4.07, and $v 5=3.90$. From the observation, it has verified the commercial space in this study area is fully utilized and continuously full with customers. This shows that commercial space is important in creating a sense of place in public housing, especially for adolescents.

Thus, from Table 5, the PAI index on educational institution also important to youth in public housing because young people nowadays are different from the past, they are more intelligence and understand the need of education and knowledge. Somehow, there is a need to enhance this facility to be more attractive and functional to users in creating a sense of place for the public housing in the urban area.

Table 5. Respondents' satisfaction using PAI variables

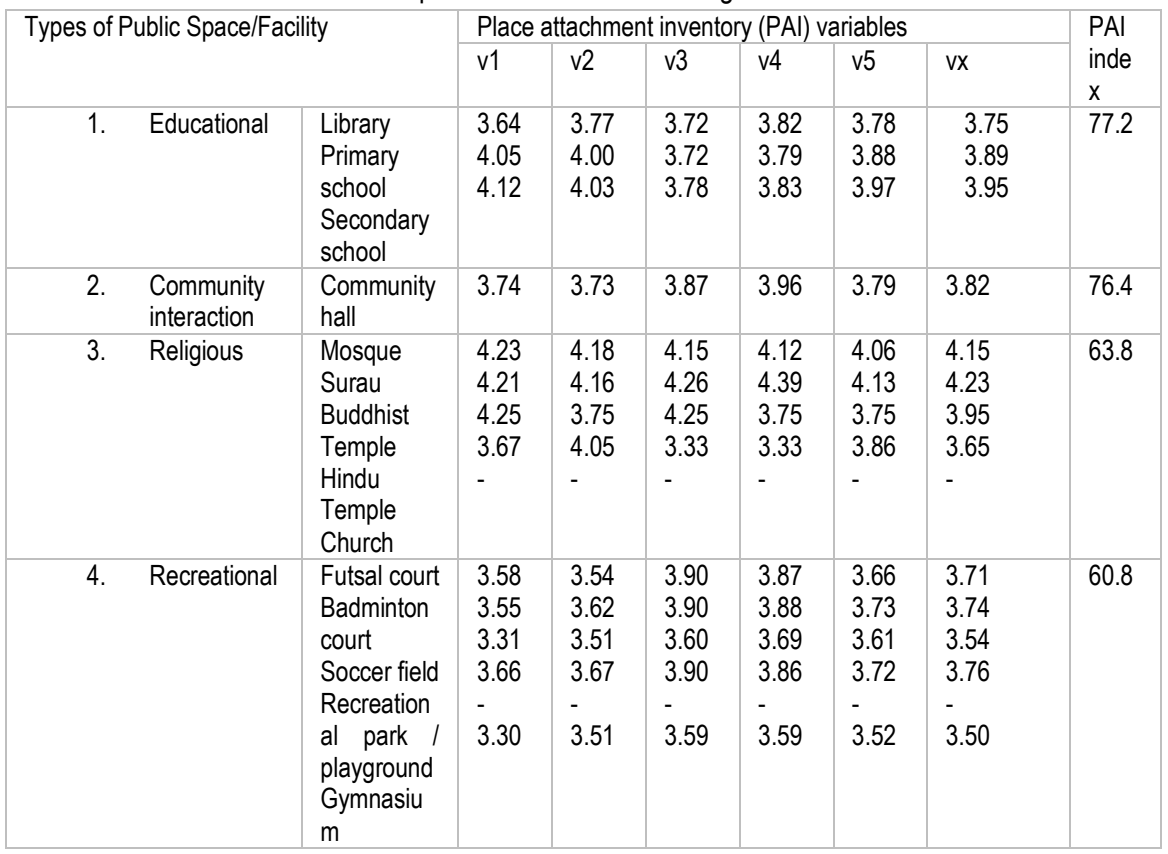




\begin{tabular}{|cl|l|l|l|l|l|l|l|l|}
\hline & & $\begin{array}{l}\text { Jogging } \\
\text { track }\end{array}$ & & & & & & & \\
\hline 5. & Health & Governme & 3.71 & 3.86 & 3.76 & 3.93 & 3.88 & 3.83 & 75.8 \\
& & 3.81 & 3.78 & 3.65 & 3.75 & 3.74 & 3.75 & \\
& & & & & & & & \\
& & $\begin{array}{l}\text { Private } \\
\text { clinic }\end{array}$ & & & & & & & \\
\hline \multirow{2}{*}{6.} & Commercial & Grocery & 4.09 & 3.92 & 4.09 & 4.09 & 3.83 & 4.00 & 79.4 \\
& & Mini mart & 3.92 & 3.95 & 3.86 & 3.95 & 3.88 & 3.91 & \\
& & Restaurant & 4.08 & 3.95 & 4.06 & 4.07 & 3.90 & 4.01 & \\
\hline
\end{tabular}

*V1-sufficiency: V2-comfortability: V3-range: V4-accessibility: V5-maintenance: Vx: overall mean variable

\subsection{Conclusion}

This study allows the role of place attachment measurements in creating places more significant, consequently supports resilient public park consumption. The significance of the public space and facility as a social interaction medium could be irritated if the efficient attachment to a place is weedy (Omar, et al., 2016b). The dependency and a sense of belonging preserve the place as the midpoint for an individual land community interaction that could contribute to improved social interaction procedure. Neighbourhood spaces and outdoor features should fit the public.

Further research engaged at illuminating the need for place attachment inventory relationship between neighbourhood design and community engagement could be simplified by a better explanation of adolescent needs to succeed as part of a community. Precisely, there must be an enhanced indulgent for the place dependency and identity of 'sense of belonging' to be achieved, whether unplanned neighbourhood environment is necessary or whether deep social attachment, involvement, encouragement, and attachment to place are compulsory.

\section{Acknowledgement}

This study is made possible by the Long-term Research Grant Scheme (LRGS 2014-0006106-42), Universiti Pendidikan Sultan Idris Perak associated with Universiti Teknologi MARA Shah Alam, and Universiti Putra Malaysia. Special thanks to the supportive supervisor and kindness co-supervisors in supporting the success of this research.

\section{References}

Akiva, T., \& Petrokubi, J. (2016). Children and Youth Services Review Growing with youth : A lifewide and lifelong perspective on youth-adult partnership in youth programs 诂, 弥枝, 69, 248-258.

Altena, A. M., Beijersbergen, M. D., \& Wolf, J. R. L. M. (2014). Children and Youth Services Review Homeless youth's experiences with shelter and community care services: Differences between service types and the relationship to overall service quality is, 46, 195-202.

Bartko, W. T. (2005). The ABCs of engagement in our-of-school programs. New Directions for Youth Development, 
$105,109-120$.

Bennett, J., 2014. Gifted places. The inalienable nature of belonging in place. Environ. Plann.: Soc. Space 32 (4), 658-671.

Bluyssen, P. M. (2010). Towards new methods and ways to create healthy and comfortable buildings. Building and Environment, 45(4), 808-818. doi:10.1016/j.buildenv.2009.08.020

Chraif, M., \& Dumitru, D. (2015). Gender Differences on Wellbeing and Quality of Life at Young Students at Psychology. Procedia - Social and Behavioral Sciences, 180(November 2014), 1579-1583. doi:10.1016/j.sbspro.2015.02.310

Gall, E. T., Sonat, C., Nazaroff, W. W., \& Unluer, C. (2016). Investigating CO 2 removal by Ca- and Mg-based sorbents with application to indoor air treatment, 110.

Hughey, S. M., Walsemann, K. M., Child, S., Powers, A., Reed, J. A., \& Kaczynski, A. T. (2016). Landscape and Urban Planning Using an environmental justice approach to examine the relationships between park availability and quality indicators , neighborhood disadvantage , and racial / ethnic composition, 148, 159-169.

Johar, F., \& Razak, M. R. (2015). The Right Attitude to Sustain the Green Neighbourhoods. Procedia - Social and Behavioral Sciences, 202(December 2014), 135-143. doi:10.1016/j.sbspro.2015.08.216

Johnstone, M. (2012). The servicescape: the social dimensions of place. Journal of Marketing Management, 28(11e12), $1399 \mathrm{e} 1418$.

Kleine, S. S., \& Menzel-Baker, S. (2004). An integrative review of material possession attachment. Academy of Marketing Science Review, 1(1), 1 e39.

Larson, R. (2000). Toward a psychology of positive youth development. American Psychologist, 55, 170-183.

Lewicka, M. (2011). Place attachment: how far have we come in the last 40 years? Journal of Environmental Psychology, 31(3), 207e230.

Lochner, K., Kawachi, I., \& Kennedy, B. P. (1999). Social capital:A guide to its measurement. Health \& Place, 5, 259-270.

Masoud, S., Sameni, T., Gaterell, M., Montazami, A., \& Ahmed, A. (2015). Overheating investigation in UK social housing flats built to the Passivhaus standard, 92, 222-235.

Mellor, D.M., Stokes, M., Firth, L., Hayashi, Y., Cummins, R., 2008. Need for belonging, relationship satisfaction, loneliness, and life satisfaction. Pers. Individ. Differ. 45, 213-218.

Miller, L., 2003. Belonging to country: a philosophical anthropology. J. Aust. Stud. 27, 215-223.

Omar, D., Omar, K. A., Othman, S., \& Yusoff, Z. M. (2016a). Youth Participation in Urban Neighbourhood Community. Procedia - Social and Behavioral Sciences, 234, 309-316. doi:10.1016/j.sbspro.2016.10.247

Omar, D., Omar, K. A., Othman, S., \& Yusoff, Z. M. (2016b). A cE-Bs2016Taipei Walkability Design for Urban Public Housing Park, (April), 9-10.

Omar, K. A., Omar, D., Othman, S., \& Yusoff, Z. M. (2016a). The Relationship between Youth Activities and Outdoor Features in Urban Neighbourhood Space. Procedia - Social and Behavioral Sciences, 234, 271-279. doi:10.1016/j.sbspro.2016.10.243

Omar, K. A., Omar, D., Othman, S., \& Yusoff, Z. M. (2016b). Reviewing Youth Facility Requirements for Low-cost 
Omar, K.A., et.al. Asian Journal of Quality of Life (AjQoL), 3(12) Jul / Aug 2018 (p.194-203)

Housing in Malaysia. Procedia - Social and Behavioral Sciences, 222, 702-709. doi:10.1016/j.sbspro.2016.05.231

Othman, S., Iskandar, M. M., \& Mohamed, N. I. (2016). A cE-Bs2016Taipei Well-Being Assessment of Youth in Urban Marginalized Community, (April), 9-10.

Rathunde, K., \& Csikszentmihalyi, M. (2006). The developing person: An experiential perspective. In R. M. Lerner, $\&$ W. Damon (Eds.), Handbook of child psychology (6th ed.): Vol 1, Theoretical models of human development (pp. 465-515). Hoboken, NJ: John Wiley \& Sons.

Williams, D. R., \& Stewart, S. I. (1998). Sense of place. Journal of Forestry, 98, 18-23. 